\title{
Employers' Needs for Employability Skills of Engineering Graduates in Indonesia
}

\author{
Wasimudin Surya S \\ Department of Electrical Engineering Education \\ Indonesia University of Education, Bandung, INDONESIA \\ wasimudin@upi.edu
}

\begin{abstract}
Employers hire people with the technical or workspecific skills required to do the job. But they're also looking for an additional set of skills that they often consider just as important-employability skills. This study was conducted to examine the employer's needs about the employability skills of engineering graduates in Indonesia. Data obtained by examining 250 job advertisements from companies that need workers in the fields of engineering, including electrical engineering, mechanical/automotive engineering, chemical engineering, industrial engineering, and oil/gas engineering. Selected companies are companies operating in Indonesia that provide salary above the minimum wage. The results of the study showed no statistically significant difference in the employability skills needs among the various types of engineering fields. The study finds that beyond the work-specific skills, foreign languages (especially English), communications, and computer/ICT skills was the skills of the most expected by employers for graduates of engineering colleges/schools in Indonesia. The study also found that the ability to use MS Office and Autocad was the most expected computer/ICT skills.
\end{abstract}

Index Terms - employability skills, engineering graduates.

\section{Introduction}

According to data from Badan Pusat Statistik (BPS Statistics Indonesia), the number of unemployed in Indonesia in August 2013 reached 7.4 million people, with open unemployment rate $^{1}$ of $6.25 \%$. This number has increased compared to February 2013 (5.92\%) and August 2012 (6.14\%). The highest open unemployment rates are recorded for graduates from Vocational High School (Sekolah Menengah Kejuruan - SMK) and Senior High School (Sekolah Menengah Atas - SMA). The complete data is given in Table I.

One of the reasons why many students continue their studies at university is to enhance their employment prospects. However, while good academic qualifications are highly valued, they no longer seem to be sufficient to secure employment [1]. Due to technological developments and the expanding international orientation of many companies, labour market demands have changed. Traditional 'hard' selection criteria like educational background still count, but are not sufficient anymore. Many argue that individual, 'soft' personality characteristics have become increasingly important, because the workers need to be more flexible to keep up with the continuous changes and developments [2]. This leads to changes in the personnel selection process where progressively the emphasis is put on so-called soft factors like communication skills and certain personality traits [3].

TABLE I.

UNEMPLOYMENT RATE OF POPULATION AGED 15 YEARS AND OVER BY EDUCATIONAL ATTAINMENT, 2012-2013 (PERCENT)

\begin{tabular}{|c|c|c|c|c|}
\hline \hline \multirow{2}{*}{$\begin{array}{c}\text { Educational } \\
\text { Attaintment }\end{array}$} & \multicolumn{2}{|c|}{$\mathbf{2 0 1 2}$} & \multicolumn{2}{c|}{$\mathbf{2 0 1 3}$} \\
\cline { 2 - 5 }$(\mathbf{1})$ & February & August & February & August \\
\hline (2) & $\mathbf{( 3 )}$ & $\mathbf{( 4 )}$ & $\mathbf{( 5 )}$ \\
\hline Slementary School & 3.69 & 3.64 & 3.61 & 3.51 \\
\hline Junior High School & 7.80 & 7.76 & 8.24 & 7.60 \\
\hline Senior High School & 10.34 & 9.60 & 9.39 & 9.74 \\
\hline Vocational High School & 9.51 & 9.87 & 7.68 & 11.19 \\
\hline Diploma I/II/III & 7.50 & 6.21 & 5.65 & 6.01 \\
\hline University & 6.95 & 5.91 & 5.04 & 5.50 \\
\hline Total & $\mathbf{6 . 3 2}$ & $\mathbf{6 . 1 4}$ & $\mathbf{5 . 9 2}$ & $\mathbf{6 . 2 5}$ \\
\hline \hline
\end{tabular}

Source: Badan Pusat Statistik [4]

Turns out, the skills and education recent college graduates acquired during their time on campus might not be serving them well when it comes to proving their worth to potential employers. As written by Vasel in Fox Business [5], "According to a 2013 study by American Express (AXP) and Gen $Y$ research firm Millennial Branding, managers have an overall negative view of young workers, and point to their lack of soft skills regarding communication and interpersonal interactions, time management abilities and willingness to work as a team".

A survey by York College of Pennsylvania's Center for Professional Excellence shows that many college faculty members do not think upperclassmen show a level of professionalism expected in today's working world. Almost $40 \%$ of faculty responded that less than half of students demonstrate professionalism. But these skills are hard to teach in a classroom setting, and tend to come with officelike experience whether it's from an internship, volunteer work, participating in student organizations or part-time jobs [5].

${ }^{1}$ Open unemployment is a condition in which people have no work to do. They are able to work and are also willing to work but there is no work for them. The unemployment rate is the number of people unemployed as a percentage of the labour force. 


\section{Employability Skills}

\section{A. Definitions}

The ILO defines employability skills as:

\begin{abstract}
... the skills, knowledge and competencies that enhance a worker's ability to secure and retain a job, progress at work and cope with change, secure another job if he/she so wishes or has been laid off and enter more easily into the labour market at different periods of the life cycle. Individuals are most employable when they have broadbased education and training, basic and portable high-level skills, including teamwork, problem solving, information and communications technology (ICT) and communication and language skills. This combination of skills enables them to adapt to changes in the world of work.
\end{abstract}

York [1] defines employability skills as "a set of achievements - skills, understandings and personal attributes - that make graduates more likely to gain employment and to be successful in their chosen occupations, which benefits themselves, the workforce, the community and the economy."

In Australia, employability skills are based on ten skill areas, recognised in the Core Skills for Work Developmental Framework (CSfW). Each skill area is grouped under a general skill category, which relate to the ability to navigate the world of work, interact and communicate with others in work environments, and get work done.

The UK Commission for Employment and Skills report 'The Employability Challenge' [6] has drawn on the most commonly used definitions of employability: "We take employability skills to be the skills almost everyone needs to do almost any job. They are the skills that must be present to enable an individual to use the more specific knowledge and technical skills that their particular workplaces will require".

The Confederation for British Industry's (CBI) [7] defines them as;

"A set of attributes, skills and knowledge that all labour market participants should possess to ensure they have the capability of being effective in the workplace - to the benefit of themselves, their employer and the wider economy."

In the Indonesian context, employability is usually associated with how quickly a graduate finds employment. As a result, the waiting period for seeking employment dominates the indicator of whether an institution is able to produce qualified graduates for the job market [8].
B. Important skills and capabilities when recruiting higher education graduates

Table II gives an impression about the skills and capabilities needed by companies today when recruiting university graduates, according to a survey conducted by the Flash Eurobarometer in 2010 in the 27 EU Member States involving 7036 companies.

TABLE II.

IMPORTANCE OF VARIOUS SKILLS AND CAPABILITIES WHEN RECRUITING HIGHER EDUCATION GRADUATES

\begin{tabular}{|l|c|c|c|c|c|}
\hline \multirow{2}{*}{ Skills } & \multicolumn{5}{|c|}{ The Degree of Importance (\% of answer) } \\
\cline { 2 - 6 } & $\begin{array}{c}\text { Very } \\
\text { impor- } \\
\text { tant }\end{array}$ & $\begin{array}{c}\text { Rather } \\
\text { Impor- } \\
\text { tant }\end{array}$ & $\begin{array}{c}\text { Rather } \\
\text { un-im- } \\
\text { portan } \\
\text { t }\end{array}$ & $\begin{array}{c}\text { Not } \\
\text { impor } \\
\text {-tant } \\
\text { at all }\end{array}$ & $\begin{array}{l}\text { Don't } \\
\text { Know/No } \\
\text { Answer }\end{array}$ \\
\hline Teamwork skills & 67 & 31 & 2 & 0 & 0 \\
\hline Sector-specific skills & 62 & 29 & 6 & 2 & 1 \\
\hline $\begin{array}{l}\text { Communications } \\
\text { skills }\end{array}$ & 60 & 36 & 3 & 1 & 0 \\
\hline Computer skills & 60 & 35 & 3 & 1 & 1 \\
\hline $\begin{array}{l}\text { Ability to adapt and } \\
\text { act in new situations }\end{array}$ & 60 & 37 & 2 & 0 & 1 \\
\hline $\begin{array}{l}\text { Good reading/ } \\
\text { writing skills }\end{array}$ & 59 & 36 & 3 & 1 & 1 \\
\hline $\begin{array}{l}\text { Analytical and prob- } \\
\text { lem-solving skills }\end{array}$ & 58 & 37 & 4 & 1 & 0 \\
\hline $\begin{array}{l}\text { Planning and } \\
\text { organisational skills }\end{array}$ & 53 & 42 & 4 & 1 & 0 \\
\hline $\begin{array}{l}\text { Decision-making } \\
\text { kkills }\end{array}$ & 46 & 45 & 7 & 1 & 1 \\
\hline Good with numbers & 40 & 48 & 8 & 2 & 2 \\
\hline $\begin{array}{l}\text { Foreign language } \\
\text { skills }\end{array}$ & 33 & 34 & 22 & 11 & 0 \\
\hline
\end{tabular}

Source: Flash Eurobarometer [9]

In terms of rating certain skills and capabilities as being "very important," recruiters were most likely to highlight the importance of teamwork (67\%), followed by sectorspecific skills, communication skills, computer literacy, being able to adapt to new situations, first-class ability in reading/writing, and analytical and problem-solving skills (all 58\%-62\%).

When asked about the skills and capabilities that would be most important for future higher-education graduates (in 5 to 10 years henceforth), more than 4 in 10 (45\%) employers selected sector-specific skills, and a similar proportion $(43 \%)$ mentioned basic capabilities, such as having good numeracy, literacy and computer skills. About 4 in $10(39 \%)$ respondents felt that communication skills would be important for future higher-education graduates, and $37 \%$ said the same about teamwork skills. The data is given in Table III.

TABLE III.

OPINIONS ABOUT THE SKILLS AND CAPABILITIES THAT HIGHER EDUCATION GRADUATES SHOULD HAVE IN THE NEXT 5 TO 10 YEARS

\begin{tabular}{|l|c|}
\hline \multicolumn{1}{|c|}{ Skills } & $\begin{array}{c}\text { Percen } \\
\text {-tage }\end{array}$ \\
\hline Sector-specific skills & 45 \\
\hline $\begin{array}{l}\text { Basic skills such as being good with numbers, } \\
\text { good reading and writing skills, computer skills }\end{array}$ & 43 \\
\hline Communication skills & 39 \\
\hline Teamwork skills & 37 \\
\hline Analytical and problem-solving skills & 32 \\
\hline
\end{tabular}




\begin{tabular}{|l|c|}
\hline Foreign language skills & 31 \\
\hline Ability to adapt to and act in new situations & 25 \\
\hline Planning and organisational skills & 22 \\
\hline Other & 2 \\
\hline DK/NA & 2 \\
\hline
\end{tabular}

Source: Flash Eurobarometer [9]

\section{International Perspectives on Employability}

Little [10] discusses employability in an international perspective. The purpose of Little's paper was to draw together information and data from a number of different countries that have a bearing on issues relating to graduate employability and from which lessons may be learned in the context of current 'employability' developments in the UK. Table IV lists the 10 most highly-rated competencies possessed by UK, European and Japanese graduates at time of graduation.

\section{Methodology}

This study was conducted to examine the employer's needs about the employability skills of engineering graduates in Indonesia. Data obtained by examining 250 job advertisements appearing in the major graduate recruitment on-line databases from companies that need workers in the fields of engineering, including electrical engineering, mechanical/automotive engineering, chemical engineering, industrial engineering, and oil/gas engineering. Selected companies are companies operating in Indonesia that provide salary above the minimum wage. Advertisements for fulltime permanent positions in each of these fields which stated that applicants should possess particular personal skills were analysed and coded. The advertisements examined came out during January - August 2014.

\section{Results and Discussions}

From a total of 250 ads chosen, $20 \%$ were in electrical engineering, 20\% in Mechanical/Automotive Engineering, $20 \%$ in Chemical Engineering, $20 \%$ in Industrial Engineering and $20 \%$ in Oil/Gas Engineering fields. Table V gives a breakdown of all the skills that were mentioned in the sample of 250 advertisements.

TABLE IV

THE TOP TEN COMPETENCIES POSSESSED AT TIME OF GRADU ATION (GRADUATES' OWN RATINGS)

\begin{tabular}{|ll|ll|ll|}
\hline \multicolumn{1}{|c|}{ UK } & \multicolumn{1}{|c|}{ Europe } & Japan \\
\hline 1 & Learning abilities & 1 & $\begin{array}{l}\text { Learning } \\
\text { abilities }\end{array}$ & 1 & $\begin{array}{l}\text { Loyalty, } \\
\text { integrity }\end{array}$ \\
\hline 2 & $\begin{array}{l}\text { Working } \\
\text { independently }\end{array}$ & 2 & $\begin{array}{l}\text { Power of } \\
\text { concentration }\end{array}$ & 2 & $\begin{array}{l}\text { Power of } \\
\text { concentration }\end{array}$ \\
\hline 3 & $\begin{array}{l}\text { Written } \\
\text { communication } \\
\text { skills }\end{array}$ & 3 & $\begin{array}{l}\text { Working } \\
\text { independently }\end{array}$ & 3 & Adaptability \\
\hline 4 & $\begin{array}{l}\text { Working in a } \\
\text { team }\end{array}$ & 4 & $\begin{array}{l}\text { Written } \\
\text { communication } \\
\text { skills }\end{array}$ & 4 & $\begin{array}{l}\text { Getting } \\
\text { personally } \\
\text { involved }\end{array}$ \\
\hline 5 & $\begin{array}{l}\text { Working under } \\
\text { pressure }\end{array}$ & 5 & $\begin{array}{l}\text { Loyalty, } \\
\text { integrity }\end{array}$ & 5 & $\begin{array}{l}\text { Learning } \\
\text { abilities }\end{array}$ \\
\hline 6 & $\begin{array}{l}\text { Accuracy, } \\
\text { attention to detail }\end{array}$ & 6 & $\begin{array}{l}\text { Field-specific } \\
\text { theoretical } \\
\text { knowledge }\end{array}$ & 6 & $\begin{array}{l}\text { Field-specific } \\
\text { theoretical } \\
\text { knowledge }\end{array}$ \\
\hline 7 & $\begin{array}{l}\text { Power of } \\
\text { concentration }\end{array}$ & 7 & $\begin{array}{l}\text { Getting } \\
\text { personally } \\
\text { involved }\end{array}$ & 7 & Fitness for work \\
\hline 8 & $\begin{array}{l}\text { Oral } \\
\text { communication } \\
\text { skills }\end{array}$ & 8 & Critical thinking & 8 & Initiative \\
\hline 9 & Problem-solving & 9 & Adaptability & 9 & Tolerance \\
\hline
\end{tabular}

\begin{tabular}{|c|c|c|c|}
\hline ability & & & \\
\hline $\begin{array}{l}10=\text { Initiative } \\
10=\text { Adaptability } \\
10=\text { Tolerance }\end{array}$ & 10 Tolerance & 10 & $\begin{array}{l}\text { Working in a } \\
\text { team }\end{array}$ \\
\hline
\end{tabular}

SKILLS REQUIREMENTS SPECIFIED IN A SAMPLE OF $250 \mathrm{JOB}$ ADVERTISEMENTS

\begin{tabular}{|l|c|l|c|}
\hline \multicolumn{1}{|c|}{ Skills } & $\begin{array}{c}\text { Number of ads } \\
\text { in which } \\
\text { mentioned }\end{array}$ & \multicolumn{1}{|c|}{ Skills } & $\begin{array}{c}\text { Number of ads } \\
\text { in which } \\
\text { mentioned }\end{array}$ \\
\hline \multicolumn{1}{|c|}{$(1)$} & $(2)$ & \multicolumn{1}{|c|}{$(1)$} & $(2)$ \\
\hline $\begin{array}{l}\text { Foreign language } \\
\text { (English) }\end{array}$ & $157(62.8 \%)$ & Working hard & $60(24.0 \%)$ \\
\hline Communication & $154(61.6 \%)$ & Self motivated & $48(19.2 \%)$ \\
\hline Computer/ICT & $150(60.0 \%)$ & Honest & $42(16.8 \%)$ \\
\hline Teamwork & $136(54.4 \%)$ & Discipline & $39(15.6 \%)$ \\
\hline Analytical & $82(32.8 \%)$ & Problem-Solving & $35(14.0 \%)$ \\
\hline $\begin{array}{l}\text { Working under } \\
\text { pressure }\end{array}$ & $80(32.0 \%)$ & Detail & $35(14.0 \%)$ \\
\hline Interpersonal & $78(31.2 \%)$ & Responsibility & $34(13.6 \%)$ \\
\hline Leadership & $77(30.8 \%)$ & & \\
\hline
\end{tabular}

Table $\mathrm{V}$ shows that beyond the work-specific skills, foreign languages (62.8\%), communications (61.6\%), computer/ICT $(60,0 \%)$, and teamwork skills (54.4\%) was the skills of the most expected by employers for graduates of engineering colleges/schools in Indonesia. The finding of this research was quite similar with findings by Omar et al. [11] which arrayed communications, computer/ICT, foreign language, and teamwork skills as major employability skills required by employers during recruitment process.

The fact that the language and communication skills occupy the top of employability skills is not surprising. Education and skills survey results conducted by the CBI in 2013 [12] showed that:

- Nearly three quarters (72\%) of businesses say they value foreign language skills among their employees, particularly in helping build relations with clients, customers and suppliers (39\%);

- One in five firms $(21 \%)$ is concerned that weaknesses in foreign language proficiency are losing them business or is uncertain whether this is happening;

- Among firms concerned about shortfalls in language proficiency, half $(52) \%$ are looking to recruit staff with the appropriate skills.

Concerning foreign language skills, majority ads requested graduates who were able to write and speak fluently in foreign language. Roughly, more than $60 \%$ ads in all of five engineering fields required languages proficiency mainly in English. For many employers, no skill is more valuable than a foreign language. Learning another language not only provides students with enhanced communication skills but demonstrates to employers that they are committed, motivated and commercially aware of the global economy. Globalisation means that business is increasingly taking place across international boundaries. In order to penetrate foreign markets successfully, employers need 
graduates who speak the language(s) of the country in which they wish to make an impact.

Communication is the process by which we exchange information between individuals or groups of people. It is a process where we try as clearly and accurately as we can, to convey our thoughts, intentions and objectives. Good communication skills are key to success in life, work and relationships. Without effective communication, a message can turn into error, misunderstanding, frustration, or even disaster by being misinterpreted or poorly delivered.

Advances in technology such as the internet should help improve communication skills of graduates of higher education. But the facts show different things. Despite their persistent use of social media and texting, a top complaint from employers about Millennial-age workers is their lack of communication skills. "Younger people are communicating at great levels but it's through technology," says Lauren Stiller, author of You Raised Us, Now Work With Us. "This means their verbal communication skills are diminished. They are talking less to each other and their other communication skills are highly abbreviated and perfunctory" [5].

It was indeed the case that advertisements for certain types of occupation tended to demand particular sets of skills. Table VI shows the percentages of advertisements citing specific employability skills for jobs in various engineering fields. It can be seen that $74,00 \%$ of the advertisements for electrical enginering field jobs demanded that applicants have foreign language skills, 58,00\% required communication skills, $68,00 \%$ computer/ICT skills and $60,00 \%$ teamwork skills. Communication skill is a skill that is most needed in the field of industrial and oil/gas engineering. Mechanical engineering jobs tended to require computer/ICT, communications and teamwork skills, while electrical and chemical engineering prefers foreign language and computer/ICT skills.

TABLE VI.

SKILLS SPECIFIED IN ADVERTISEMENTS FOR JOBS IN VARIOUS ENGINEERING FIELDS

\begin{tabular}{|c|l|l|l|l|l|l|}
\hline No & \multicolumn{1}{|c|}{ Skills } & $\begin{array}{c}\text { Electrical } \\
\text { Engi- } \\
\text { neering }\end{array}$ & $\begin{array}{c}\text { Mecha- } \\
\text { nical } \\
\text { Engi- } \\
\text { neering }\end{array}$ & $\begin{array}{c}\text { Chemi- } \\
\text { cal Engi- } \\
\text { neering }\end{array}$ & $\begin{array}{c}\text { Indus- } \\
\text { trial } \\
\text { Engi- } \\
\text { neering }\end{array}$ & $\begin{array}{c}\text { Oil/ Gas } \\
\text { Engineering }\end{array}$ \\
\hline 1 & $\begin{array}{l}\text { Foreign } \\
\text { language }\end{array}$ & $74,00 \%$ & $46,00 \%$ & $70,00 \%$ & $60,00 \%$ & $64,00 \%$ \\
\hline 2 & $\begin{array}{l}\text { Communi- } \\
\text { cation }\end{array}$ & $58,00 \%$ & $60,00 \%$ & $52,00 \%$ & $66,00 \%$ & $72,00 \%$ \\
\hline 3 & $\begin{array}{l}\text { Computer/ } \\
\text { ICT }\end{array}$ & $68,00 \%$ & $66,00 \%$ & $58,00 \%$ & $52,00 \%$ & $56,00 \%$ \\
\hline 4 & Teamwork & $60,00 \%$ & $60,00 \%$ & $54,00 \%$ & $48,00 \%$ & $50,00 \%$ \\
\hline 5 & Analytical & $32,00 \%$ & $28,00 \%$ & $36,00 \%$ & $42,00 \%$ & $26,00 \%$ \\
\hline 6 & $\begin{array}{l}\text { Working } \\
\text { under } \\
\text { pressure }\end{array}$ & $34,00 \%$ & $46,00 \%$ & $34,00 \%$ & $28,00 \%$ & $18,00 \%$ \\
\hline 7 & $\begin{array}{l}\text { Interperso- } \\
\text { nal }\end{array}$ & $42,00 \%$ & $28,00 \%$ & $24,00 \%$ & $32,00 \%$ & $30,00 \%$ \\
\hline 8 & Leadership & $34,00 \%$ & $28,00 \%$ & $26,00 \%$ & $46,00 \%$ & $20,00 \%$ \\
\hline 9 & $\begin{array}{l}\text { Working } \\
\text { hard }\end{array}$ & $28,00 \%$ & $26,00 \%$ & $30,00 \%$ & $26,00 \%$ & $10,00 \%$ \\
\hline 10 & $\begin{array}{l}\text { Self } \\
\text { motivated }\end{array}$ & $24,00 \%$ & $18,00 \%$ & $18,00 \%$ & $18,00 \%$ & $18,00 \%$ \\
\hline 11 & Honest & $14,00 \%$ & $30,00 \%$ & $22,00 \%$ & $10,00 \%$ & $8,00 \%$ \\
\hline 12 & Discipline & $12,00 \%$ & $20,00 \%$ & $26,00 \%$ & $10,00 \%$ & $10,00 \%$ \\
\hline 13 & $\begin{array}{l}\text { Problem- } \\
\text { Solving }\end{array}$ & $12,00 \%$ & $12,00 \%$ & $14,00 \%$ & $16,00 \%$ & $16,00 \%$ \\
\hline 14 & Detail & $10,00 \%$ & $28,00 \%$ & $16,00 \%$ & $14,00 \%$ & $2,00 \%$ \\
\hline 15 & $\begin{array}{l}\text { Responsi- } \\
\text { bility }\end{array}$ & $14,00 \%$ & $22,00 \%$ & $20,00 \%$ & $6,00 \%$ & $6,00 \%$ \\
\hline
\end{tabular}

Data analysis using chi-squared test showed that there was no statistically significant difference in the employability skills needs among the various types of engineering fields. All engineering fields require similar attribute of employability skills, ranging from communication skills, foreign language skills, computer/ICT skills, teamwork skills, and so on. Employability skills are 'transferable skills' - skills that are not specific to one particular career path but are generic across all employment sectors.

The results of this study also found that for computer skills, more than $75 \%$ of companies want graduates proficient in MS Office. In addition to MS Office proficiency, for electrical and mechanical engineering fields, more than $25 \%$ of employers want graduates can operate CAD Programme/software.

Other findings from this study is that of the 250 advertisements examined, the minimum educational background required is $64 \% \mathrm{~S} 1$ (four years bachelor's or undergraduate degree) and 26\% D3 (three years diploma).

\section{Conclusion}

Employability skills are 'transferable skills' - skills that are not specific to one particular career path but are generic across all employment sectors. The results of the study showed no statistically significant difference in the employability skills needs among the various types of engineering fields. The study finds that beyond the workspecific skills, foreign languages (especially English), communications, and computer/ICT skills was the skills of the most expected by employers for graduates of engineering colleges/schools in Indonesia.The study also found that the ability to use MS Office and Autocad was the most expected computer/ICT skills.

\section{Acknowledgment}

The author would like to thank my students and colleagues at the Department of Electrical Engineering Education, Indonesia University of Education, for their suggestions and support.

\section{References}

[1] Yorke, M., "Employability in Higher Education: What it is - What it is not". York: Higher Education Academy. Reprint, 2006.

[2] Semeijn, Judith, et al., "Personality Characteristics and Labour Market Entry. An exploration". Research Center for Education and The Labour Market, Faculty of Economics and Business Administration, Maastricht University, 2000.

[3] Spencer, L.M. \& Spencer, S.M., "Competence at Work: Models for Superior Performance”. John Wiley \& Sons, Inc., United States of America, 1993.

[4] Badan Pusat Statistik, "Keadaan Ketenagakerjaan Agustus 2013". Berita Resmi Statistik. No. 78/11/Th. XVI, 6th November 2013.

[5] Vasel, Kathryn Buschman, “The Skills Employers Wish College Grads Had". [Internet: http://www.foxbusiness.com/personalfinance/2014/01/30/skills-employers-wish-college-grads-had/, 5th June 2014], 2014.

[6] UK Commission for Employment and Skills, "The Employability Challenge, Full Report”. Learning and Skills Network (LSN), United Kingdom, 2009.

[7] CBI, "Future Fit - Preparing graduates for the world of work" [Internet: http://mycourse.solent.ac.uk/mod/resource/view.php?id=176535, 4th May 2014], 2007. 
[8] Syafiq, A. \& Fikawati, S., "Tracer Study University of Indonesia Final Report". Jakarta, Universitas Indonesia, Career Development Center, 2008.

[9] Flash Eurobarometer, "Employers' perception of graduate employability, Analytical report". Survey conducted by The Gallup Organization, Hungary upon the request of Directorate-General for Education and Culture and coordinated by Directorate-General Communication, European Commission, 2010.

[10] Little, Brenda, "International Perspective on Employability". Enhancing Student Employability Co-ordination Team \& LTSN Generic Centre, United Kingdom, 2003.

[11] Omar, Nik Hairi, et al., "Graduate's Employability Skills Based On Current Job Demand through Electronic Advertisement". Asian Social Science. Vol. 8, No. 9, July 2012. Canadian Center of Science and Education, 2012.

[12] CBI, "Changing the pace: $\mathrm{CBI} /$ Pearson education and skills survey 2013”. London: CBI, 2013. 